\title{
Penghitungan BPHTB serta PPh dalam Jual Beli Tanah dan/atau Bangunan Berbasis WebGIS (Studi Kasus: Kota Solok, Provinsi Sumatera Barat)
}

\author{
Wafa Zakkiyah, Yanto Budisusanto, dan Andy Dediyono \\ Departemen Teknik Geomatika, Institut Teknologi Sepuluh Nopember (ITS) \\ e-mail: yanto_b@eodesy.its.ac.id
}

\begin{abstract}
Abstrak-Wilayah administrasi Kota Solok yang berbatasan dengan Kabupaten Solok dan Kota Padang menyebabkan Kota Solok memiliki peran sentral dalam menunjang perekonomian masyarakat Kota Solok dan Kabupaten Solok. Keunggulan geografis ini menyebabkan Kota Solok mengalami peningkatan jumlah penduduk. Dengan luas wilayah $57.64 \mathbf{~ k m}^{2}$, jumlah penduduk Kota Solok pada tahun 2016 sebanyak 67.307 jiwa, tahun 2017 sebanyak 68.602 jiwa. Peningkatan jumlah penduduk Kota Solok berpengaruh terhadap meningkatnya NJOP. NJOP dijadikan dasar dalam menentukan besarnya nilai BPHTB serta PPh dalam jual beli tanah dan/atau bangunan. BPHTB merupakan pajak yang dikenakan kepada pembeli, sedangkan PPh merupakan pajak yang dikenakan kepada penjual. Belum terdapat fasilitas yang dapat memudahkan Pemda dalam melakukan pembaruan data NJOP. Dari pihak masyarakat serta PPAT/Notaris, belum terdapat fasilitas untuk memperoleh informasi mengenai besarnya nilai BPHTB serta PPh secara terbuka. Selain itu, belum terdapat webGIS zona nilai tanah di Kota Solok. Dari penelitian ini didapatkan bahwa WebGIS zona nilai tanah yang telah dibuat dapat memperbarui data NJOP, menghitung BPHTB serta PPh, dan menampilkan hasil penghitungan pajak dalam bentuk PDF. Besar persentase kelayakan sistem untuk uji usabilitas sebesar $80,38 \%$ dengan predikat layak serta melakukan uji portabilitas dengan mengakses webGIS zona nilai tanah Kota Solok di sepuluh web browser dan berhasil dijalankan.
\end{abstract}

Kata Kunci-BPHTB, PPh, WebGIS, Zona Nilai Tanah.

\section{PENDAHULUAN}

$\mathrm{K}$ OTA Solok merupakan sebuah kota di Provinsi Sumatera Barat. Wilayah administrasi Kota Solok berbatasan dengan Kabupaten Solok dan Kota Padang. Kota Solok memiliki peran sentral dalam menunjang perekonomian masyarakat Kota Solok dan Kabupaten Solok pada umumnya [1]. Keunggulan geografis ini menyebabkan Kota Solok mengalami peningkatan jumlah penduduk setiap tahunnya. Dengan luas wilayah $57.64 \mathrm{~km}^{2}$, jumlah penduduk Kota Solok pada tahun 2016 sebanyak 67.307 jiwa, dan pada tahun 2017 sebanyak 68.602 jiwa [2]. Peningkatan jumlah penduduk di Kota Solok berpengaruh terhadap meningkatnya Nilai Jual Objek Pajak (NJOP)[3]. NJOP dapat divisualisasikan menjadi peta zona nilai tanah.

NJOP dijadikan dasar dalam menentukan besarnya nilai pajak [4]. Salah satunya adalah Bea Perolehan Hak atas Tanah dan Bangunan (BPHTB) serta Pajak Penghasilan (PPh) dalam jual beli tanah dan/atau bangunan. BPHTB merupakan pajak yang dikenakan kepada pembeli,
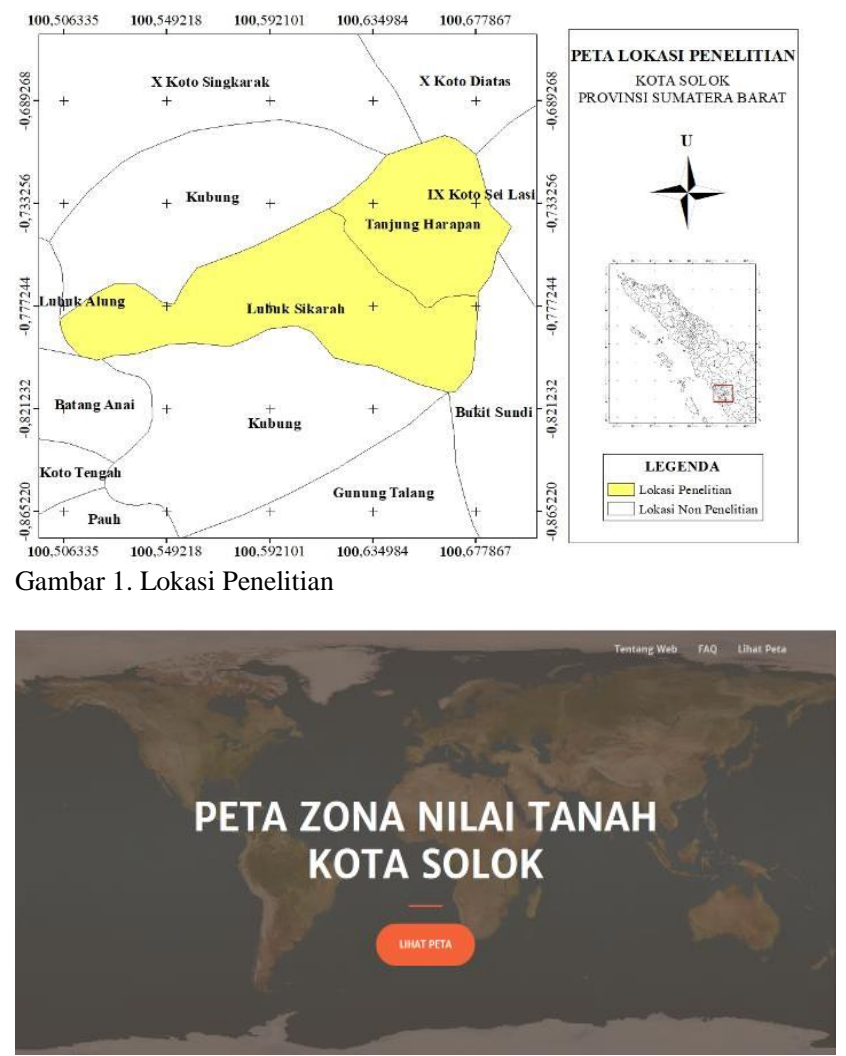

Gambar 2. Menu Beranda

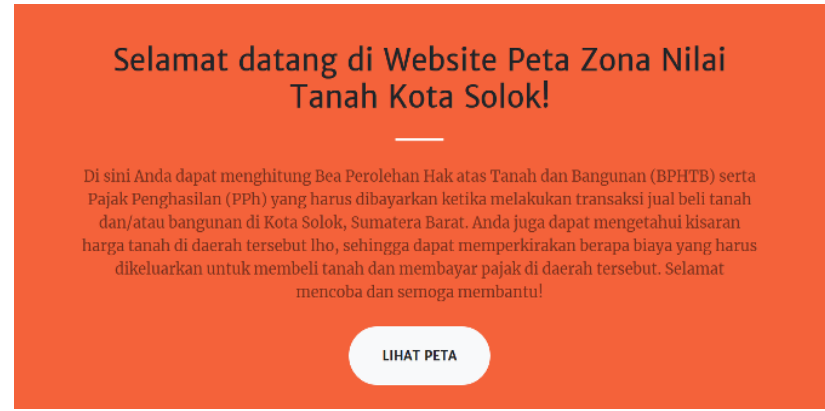

Gambar 3. Menu Tentang Web

sedangkan $\mathrm{PPh}$ merupakan pajak yang dikenakan kepada penjual pada saat jual beli tanah dan/atau bangunan. BPHTB dan $\mathrm{PPh}$ dalam transaksi jual beli tanah dan/atau bangunan menjadi penting karena merupakan suatu aktifitas yang dilakukan oleh masyarakat yang dapat memberikan pemasukan berupa pajak dalam jumlah yang relatif besar bagi negara. BPHTB akan dikelola oleh Pemerintah Daerah 


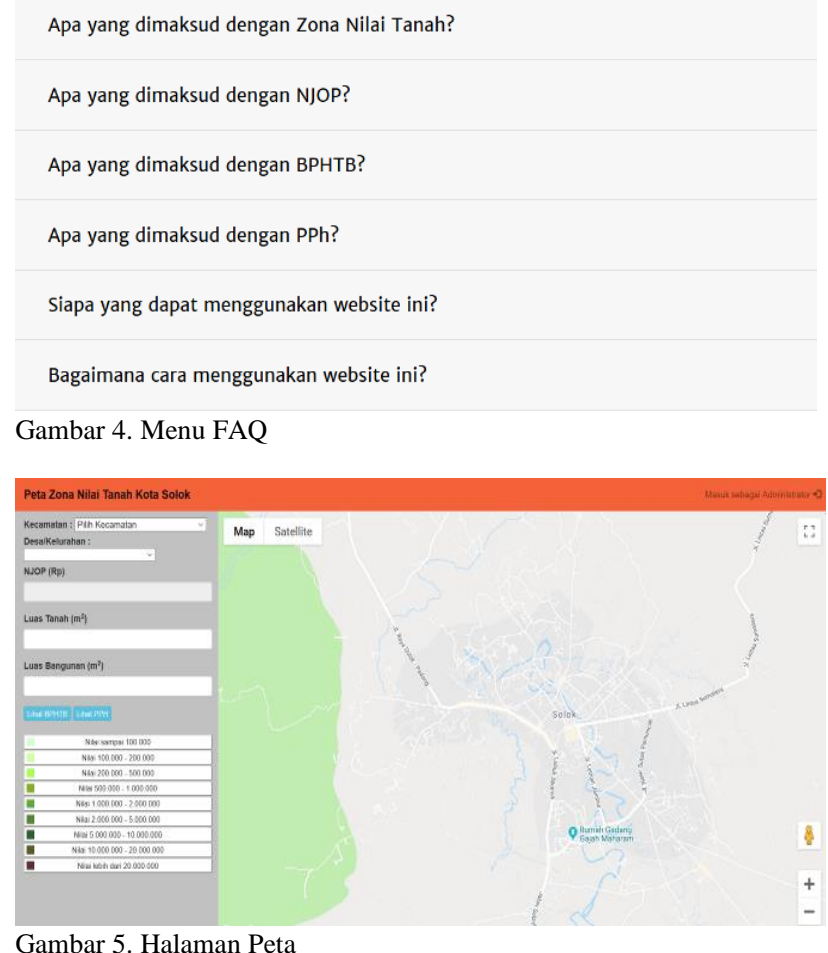

Gambar 5. Halaman Peta

\begin{tabular}{l|l|} 
Kecamatan : & Pilih Kecamatan \\
Desa/Kelurah & Pilih Kecamatan \\
\hline NJOP (Rp) & LUBUK SIKARAH \\
\hline & TANJUNG HARAPAN \\
\hline
\end{tabular}

Gambar 6. Pencarian Berdasarkan Kecamatan

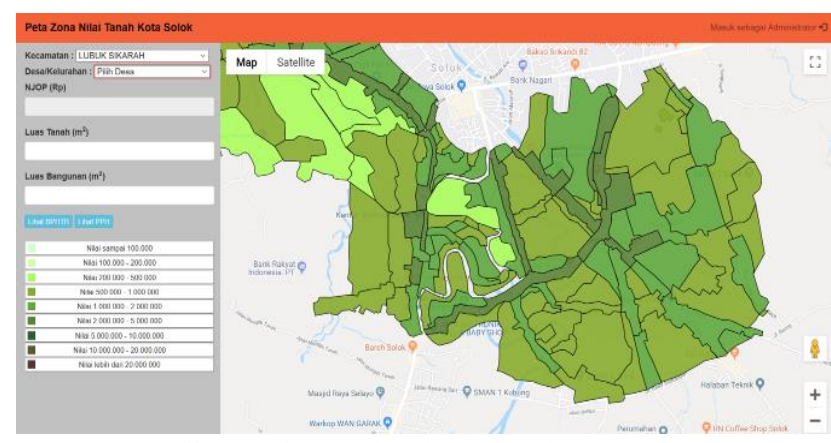

Gambar 7. Hasil Pencarian Berdasarkan Kelurahan

(Pemda), sedangkan PPh akan dikelola oleh Pemerintah Pusat [5].

Belum terdapat fasilitas yang dapat memudahkan Pemda dalam melakukan pembaruan data NJOP yang selanjutnya akan digunakan dalam penghitungan nilai BPHTB dan PPh. Dari pihak masyarakat serta PPAT/Notaris, belum terdapat fasilitas untuk memperoleh informasi tentang BPHTB dan $\mathrm{PPh}$ secara terbuka, yang dapat mempermudah masyarakat dalam mengetahui nilai BPHTB dan PPh yang harus dibayarkan pada saat melakukan jual beli tanah dan/atau bangunan. Selain itu, belum terdapat WebGIS Zona Nilai Tanah di Kota Solok. Dalam penelitian ini dilakukan pembuatan WebGIS zona nilai tanah dimana Pemda dapat melakukan pembaruan data NJOP dan masyarakat serta PPAT/Notaris dapat mengetahui nilai BPHTB dan PPh yang akan dikenakan saat melakukan jual beli tanah dan/atau bangunan. Dengan adanya WebGIS zona nilai tanah maka akan memudahkan Pemda dalam melakukan pembaruan data NJOP dan memudahkan masyarakat serta PPAT/Notaris

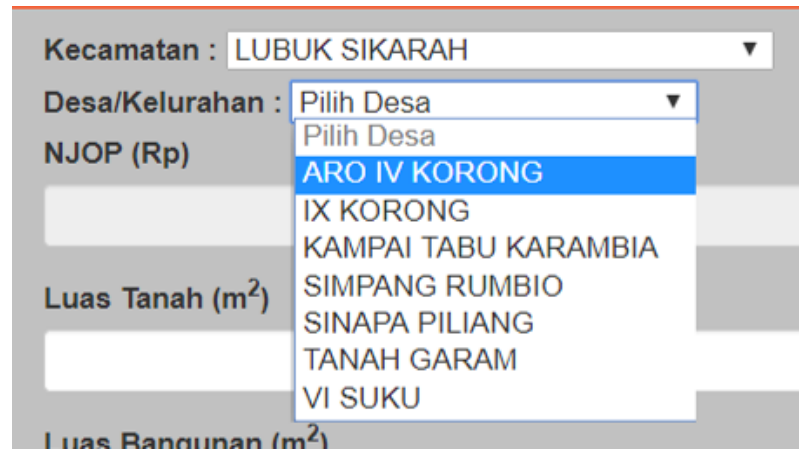

Gambar 8. Pencarian Berdasarkan Kelurahan

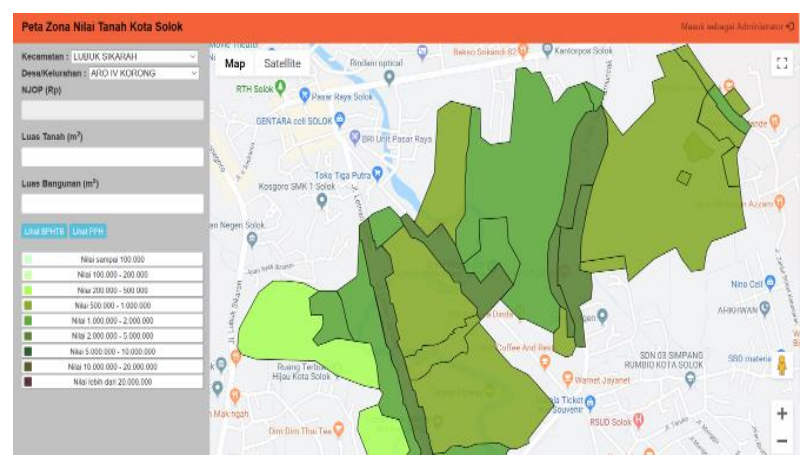

Gambar 9. Hasil Pencarian Berdasarkan Kecamatan dan Kelurahan

\begin{tabular}{|c|c|}
\hline & Nilai sampai 100.000 \\
\hline & Nilai $100.000-200.000$ \\
\hline$\square$ & Nilai $200.000-500.000$ \\
\hline$\square$ & Nilai $500.000-1.000 .000$ \\
\hline$\square$ & Nilai $1.000 .000-2.000 .000$ \\
\hline$m$ & Nilai $2.000 .000-5.000 .000$ \\
\hline$\square$ & Nilai $5.000 .000-10.000 .000$ \\
\hline - & Nilai $10.000 .000-20.000 .000$ \\
\hline$\square$ & Nilai lebih dari 20.000 .000 \\
\hline
\end{tabular}

Gambar 10. Pencarian Berdasarkan Rentang NJOP

dalam mengetahui besarnya nilai BPHTB dan PPh yang akan dikenakan pada saat melakukan jual beli tanah dan/atau bangunan. Kegiatan tersebut dapat dilakukan hanya dengan menggunakan perangkat keras, perangkat lunak, serta koneksi jaringan internet untuk mengakses situs dari WebGIS zona nilai tanah.

\section{METODOLOGI PENELITIAN}

\section{A. Lokasi Penelitian}

Lokasi dari penelitian tugas akhir ini adalah Kota Solok, Provinsi Sumatera Barat. Kota Solok terletak pada posisi $0^{\circ}$ $44^{\prime} 28^{\prime \prime} \mathrm{LU}-0^{\circ} 49^{\prime} 12^{\prime \prime} \mathrm{LS}, 100^{\circ} 32^{\prime} 42^{\prime \prime} \mathrm{BT}-100^{\circ} 41^{\prime} 12^{\prime \prime}$ BT dengan luas 57,64 $\mathrm{km}^{2}(0,14 \%$ dari luas Provinsi Sumatera Barat) dapat dilihat pada Gambar 1.

\section{B. Alat}

Alat yang digunakan pada penelitian ini adalah sebagai berikut: (1)Perangkat lunak PostgreSQL untuk membuat dan mengedit basis data; (2)Perangkat lunak PostGIS untuk memproses data spasial; (3)Perangkat lunak Sublime untuk membuat dan mengedit script PHP, CSS, dan Java Script.; (4)Perangkat lunak MS4W untuk memunculkan WebGIS melalui server localhost. 


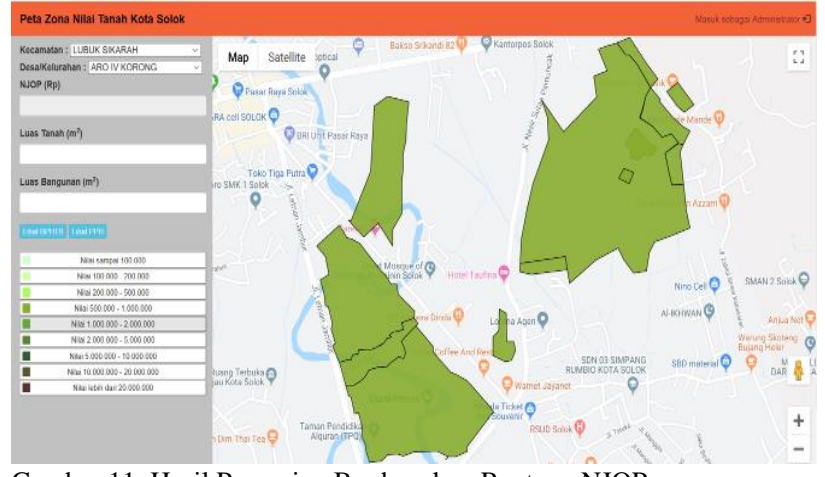

Gambar 11. Hasil Pencarian Berdasarkan Rentang NJOP

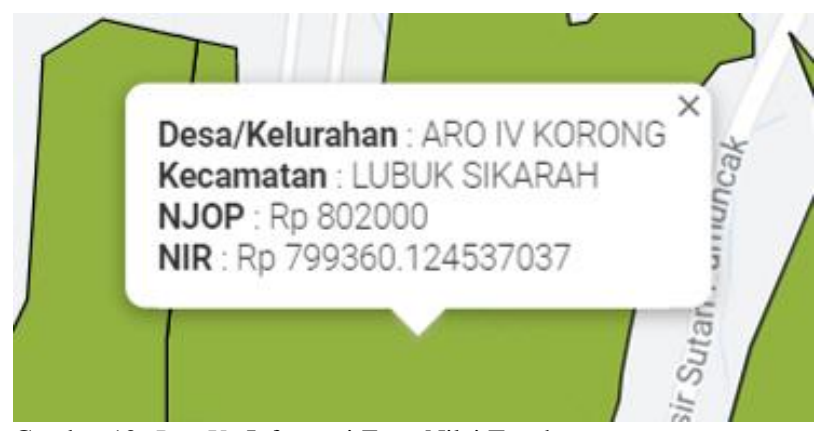

Gambar 12. Pop Up Informasi Zona Nilai Tanah

Luas Tanah $\left(\mathrm{m}^{2}\right)$
Luas Bangunan $\left(\mathrm{m}^{2}\right)$
Lihat BPHTB Lihat PPH

Gambar 13. Input Luas Tanah dan Luas Bangunan

\section{Bahan}

Bahan yang digunakan pada penelitian ini adalah sebagai berikut; (1)Peta zona nilai tanah Kota Solok tahun 2018 dalam format shapefile; (2)Google Maps API sebagai background peta zona nilai tanah; (3)Data Nilai Indikasi Rata-rata (NIR) Kota Solok tahun 2018; (4)Data Nilai Jual Objek Pajak (NJOP) Kota Solok tahun 2018.

\section{Tahapan Pembuatan WebGIS}

WebGIS zona nilai tanah Kota Solok merupakan webGIS yang diperuntukkan bagi Pemda, masyarakat, serta PPAT/Notaris. Dalam hal ini, masyarakat serta PPAT/Notaris merupakan pengguna, dimana dapat menghitung pajak yang harus dibayarkan saat terjadi transaksi jual beli tanah dan/atau bangunan, yaitu BPHTB serta PPh. Sedangkan Pemda merupakan administrator, selain dapat menghitung pajak seperti yang dapat dilakukan oleh masyarakat serta PPAT/Notaris, juga dapat memperbarui data NJOP Kota Solok. Berikut adalah tahapan pembuatan webGIS; (1)Mempersiapkan Data. Pada tahapan ini, terdapat dua data yaitu data spasial dan data nonspasial. Untuk data spasial, data peta zona nilai tanah yang telah didapatkan dikonversi ke dalam format geojson. Hal ini dilakukan agar data spasial dapat dipanggil nantinya melalui script khsusus. Sedangkan data nonspasial disimpan di dalam sebuah basis data dengan menggunakan perangkat

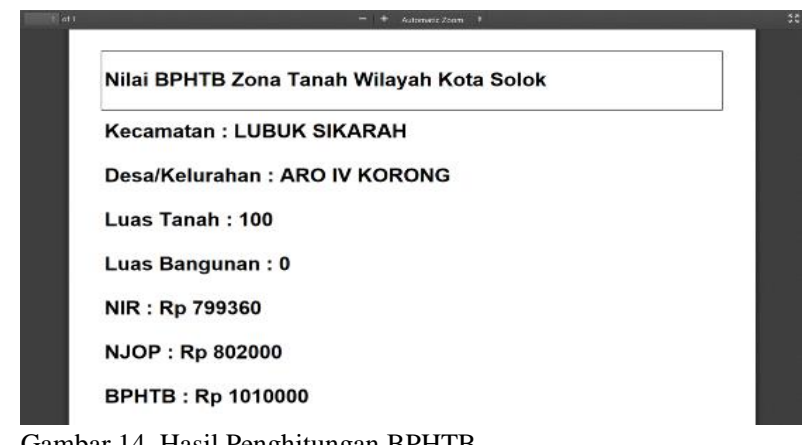

Gambar 14. Hasil Penghitungan BPHTB
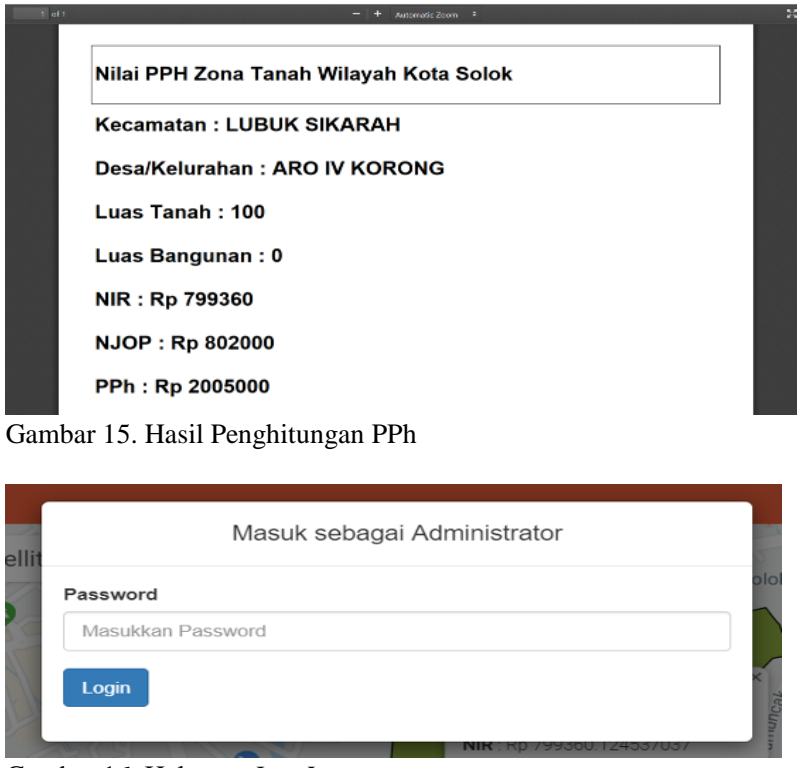

Gambar 16. Halaman Log In

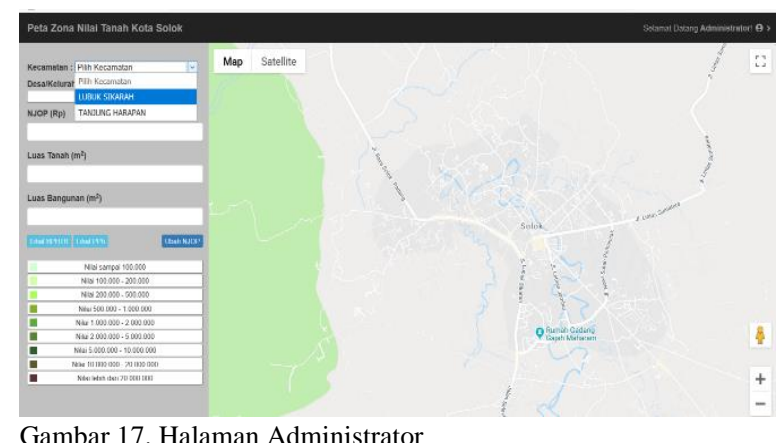

lunak PostgreSQL; (2)Scripting Pada tahapan ini dilakukan scripting menggunakan perangkat lunak Sublime, dimana terdiri dari scripting CSS untuk mendesain tampilan webGIS serta scripting fungsi menggunakan Java Script dan PHP; (3)Menjalankan Hasil Scripting. Pada tahapan ini dilakukan pengujian apakah dari script yang telah dibuat dapat dijalankan melalui server localhost menggunakan perangkat lunak MS4W. Jika program dapat dijalankan maka dapat dilanjutkan ke proses selanjutnya. Jika tidak dapat dijalankan maka dapat dinyatakan bahwa script yang telah dibuat masih memiliki kesalahan. Hasil akhir dari tahapan ini yaitu fitur utama dan fitur pendukung webGIS dapat muncul di halaman peta; (4)Uji Fitur. Setelah hasil scripting dapat dijalankan, langkah selanjutnya yaitu melakukan pengujian setiap fitur. Fitur utama meliputi pencarian data, pengolahan data, dan pembaruan data. Sedangkan fitur pendukung meliputi zooming, dan pop up. 


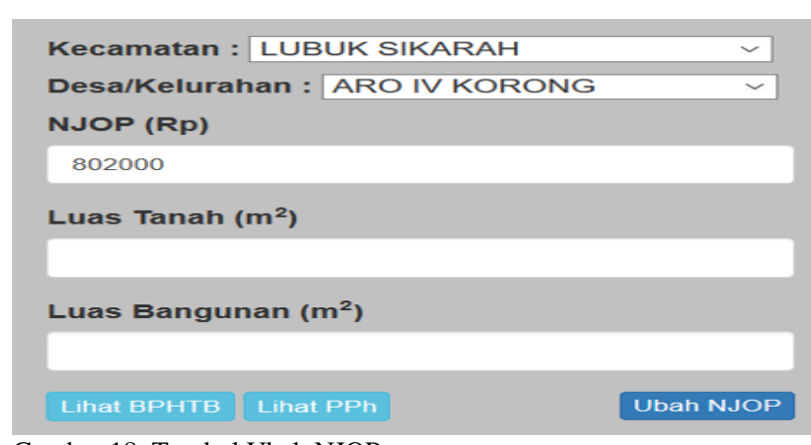

Gambar 18. Tombol Ubah NJOP

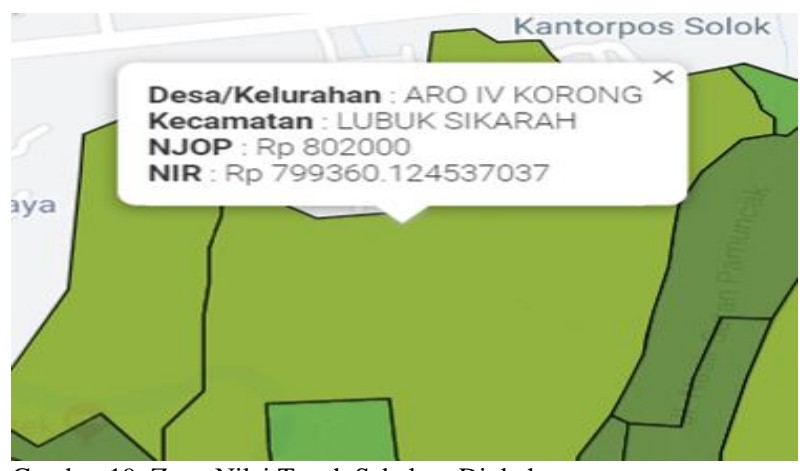

Gambar 19. Zona Nilai Tanah Sebelum Diubah

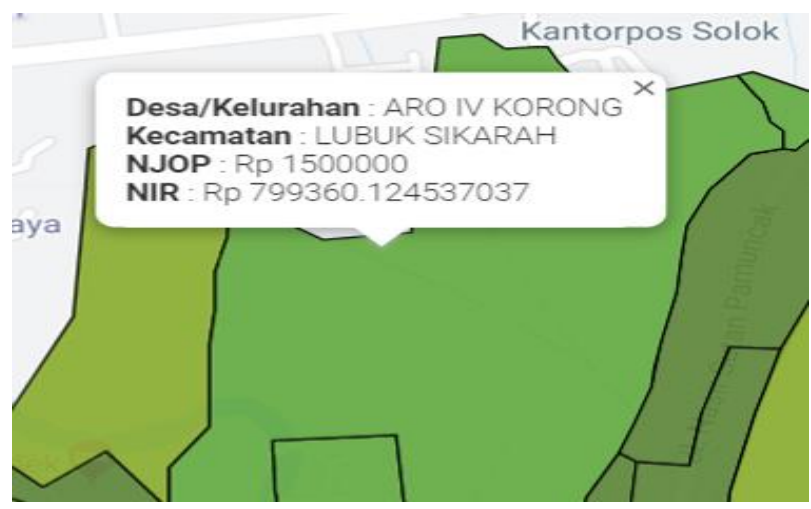

Gambar 20. Zona Nilai Tanah Setelah Diubah

\section{HASIL DAN ANALISIS}

\section{A. Analisis Hasil WebGIS}

WebGIS Zona Nilai Tanah Kota Solok terdiri dari halaman utama, halaman peta, halaman $\log$ in, dan halaman administrator antara lain:

\section{1) Halaman Beranda}

Halaman utama terdiri dari tiga menu yaitu Beranda, Tentang Web, dan Frequently Asked Question (FAQ). Menu Beranda merupakan tampilan awal dari web dimana terdapat tombol yang akan mengarah ke halaman peta dapat dilihat pada Gambar 2. Menu Tentang Web berisikan sekilas informasi dari tujuan pembangunan website ini, juga terdapat tombol yang akan mengarah ke peta dapat dilihat pada Gambar 3. Konten FAQ berisikan pertanyaan dan jawaban yang kemungkinan akan sering ditanyakan oleh pengguna dapat dilihat pada Gambar 4.

\section{2) Halaman Peta}

Halaman peta berisikan peta serta fitur-fitur yang berfungsi untuk menampilkan informasi pada peta dapat dilihat pada Gambar 5. Adapun fitur-fitur tersebut yaitu pencarian berdasarkan kelurahan dan kecamatan serta pencarian berdasarkan NJOP. Selain itu terdapat fitur input luas tanah dan luas bangunan, penghitungan nilai BPHTB dan PPh, pop up yang berisi informasi NIR dan NJOP, serta menampilkan hasil penghitungan pajak dalam bentuk PDF. Untuk mengakses fitur pencarian zona nilai tanah harus memilih kecamatan terlebih dahulu, dimana hanya terdapat dua kecamatan di Kota Solok, yaitu Kecamatan Lubuk Sikarah dan Kecamatan Tanjung Harapan. Setelah memilih kecamatan, barulah memilih kelurahan, dimana terdapat tujuh kelurahan di Kecamatan Lubuk Sikarah dan enam kelurahan di Kecamatan Tanjung Harapan. Berikut merupakan tampilan dari fitur pencarian berdasarkan nama kecamatan dan nama kelurahan dapat dilihat pada Gambar 6. Setelah dipilih kecamatan yang diinginkan, peta akan menuju kecamatan yang dipilih dapat dilihat padgambar 1a Gambar 7. Berikut ini adalah tampilan hasil pencarian berdaarkan kecamatan dapat dilihat pada Gambar 8 . Kemudian, memilih kelurahan yang diinginkan. Maka peta akan menuju kelurahan yang dipilih. Berikut ini adalah tampilan hasil pencarian berdasarkan kelurahan dapat dilihat pada Gambar 9. Setelah menuju kelurahan yang dipilih, dapat dilakukan pencarian berdasarkan rentang NJOP yang terdapat pada side bar. Berikut merupakan tampilan dari fitur pencarian berdasarkan rentang NJOP dapat dilihat pada Gambar 10.

Peta akan menuju zona nilai tanah pada rentang yang dipilih di kelurahan tersebut. Berikut ini adalah tampilan hasil pencarian berdasarkan rentang NJOP dapat dilihat pada Gambar 11. Untuk mendapatkan informasi dari suatu zona nilai tanah, klik zona nilai tanah yang diinginkan. Berikut merupakan informasi dari suatu zona nilai tanah yang ditampilkan dalam pop up dapat dilihat pada Gambar 12. Sebelum menghitung nilai BPHTB dan PPh yang harus dibayarkan pada saat jual beli tanah dan/atau bangunan pada suatu zona nilai tanah, masukkan luas tanah dan luas bangunan. Berikut merupakan tampilan dari fitur input luas tanah dan luas bangunan dapat dilihat pada Gambar 13. Setelah itu, pilih tombol "Lihat BPHTB" untuk menghitung nilai BPHTB dan pilih tombol "Lihat $\mathrm{PPh"} \mathrm{untuk}$ menghitung nilai PPh. Maka, hasil penghitungan BPHTB dan PPh akan langsung diekspor dalam bentuk PDF. Berikut merupakan tampilan dari hasil penghitungan BPHTB dan PPh dalam format PDF dapat dilihat pada Gambar 14 dan pada Gambar 15. Dimana rumus BPHTB dihitung didasarkan pada Undang-Undang No. 20 tahun 2000 pasal 8, yaitu:

\section{BPHTB $=5 \% \times(N J O P-$ NPOPTKP $)$}

Sedangkan bbesar NPOPTKP diambil nominal yang paling rendah, didasarkan pada Undang-Undang No. 34 tahun 2000, yaitu "Besarnya Nilai Perolehan Objek Pajak Tidak Kena Pajak ditetapkan paling rendah sebesar Rp60.000.000,00 (enam puluh juta rupiah) untuk setiap Wajib Pajak."

3) Halaman Log In

Sebelum memasuki halaman administrator, diharuskan melakukan $\log$ in. Log in cukup dilakukan dengan cara memasukkan password. Sebelumnya, password sudah 
diberitahukan kepada pihak yang berhak menjadi administrator, yaitu Pemda dapat dilihatpada Gambar 1 .

4) Halaman Administrator

Halaman administrator berisikan fitur-fitur yang sama dengan halaman peta, yang membedakannya adalah fitur pembaruan data NJOP dapat dilihat pada Gambar 17. Untuk mengubah data NJOP pada suatu zona nilai tanah ubahlah angka yang terdapat pada kolom NJOP. Berikut merupakan langkah-langkah untuk mengubah data NJOP anatara lain sebagai berikut: (1)Pilih suatu zona nilai tanah, apabila zona tersebut sudah terpilih, maka nilai NJOP akan ditampilkan pada side bar seperti pada Gambar 18; (2)Ubah data NJOP, kemudian pilih tombol "Ubah NJOP". Maka data NJOP akan berubah baik secara tabular (pada basis data) maupun secara spasial (pada warna peta). Berikut merupakan perbedaan sebelum dan sesudah data NJOP diubah dapat dilihat pada Gambar 19. Dapat dilihat perbedaan pada gambar sebelum dan sesudah data NJOP diubah, dimana sebelum data NJOP diubah, NJOP bernilai Rp802000,00 dan zona nilai tanah berwarna hijau muda. Sedangkan setelah data NJOP diubah, NJOP bernilai Rp1500000,00 dan zona nilai tanah berubah warna menjadi hijau tua dapat dilihat pada Gambar 20.

\section{B. Uji Kelayakan Sistem}

Uji Kelayakan Sistem terdiri dari atas 2 Uji antara lain:

1) Uji Usabilitas

Uji usabilitas dilakukan berdasarkan hasil penilaian pengguna setelah mengunjungi webGIS zona nilai tanah dan mengisi kuisioner. Pertanyaan yang terdapat dalam kuisioner mewakili 5 aspek uji usabilitas yaitu kemudahan untuk dipelajari, efisiensi, mudah diingat, kesalahan, dan kepuasan. Dimana terdapat 5 pertanyaan dari masing-masing aspek. Hasil uji kebergunaan ini diperoleh berdasarkan 35 orang responden. Berdasarkan perhitungan presentase kelayakan, didapatkan presentase sebesar $80,38 \%$ sehingga web termasuk kategori layak.

\section{2) Uji Portabilitas}

Uji portabilitas yang dilakukan yaitu mencoba menjalankan sistem ke beberapa web browser. Dalam hal ini, web browser. Dalam pengujian portabilitas, web zona nilai tanah ini dapat berjalan dengan baik di sepuluh web browser yaitu Google Chrome, Opera, Internet Explore, Mozilla Firefox, UC Browser, Microsoft Edge, Comodo Dragon, Maxthon, Vivaldi, dan Brave.

\section{KESIMPULAN}

WebGIS zona nilai tanah Kota Solok telah berhasil dibuat dengan beberapa fitur yaitu pencarian zona nilai tanah, input luas tanah dan luas bangunan, penghitungan pajak BPHTB dan $\mathrm{PPh}$, ekspor hasil penghitungan pajak dalam bentuk PDF, log in sebagai administrator, pambaruan data NJOP, FAQ, pop up, dan zooming. Besar persentase kelayakan sistem untuk uji usabilitas sebesar $80,38 \%$ dengan predikat layak dan melakukan uji portabilitas dengan mengakses webGIS zona nilai tanah Kota Solok di sepuluh web browser dan berhasil dijalankan.

\section{UCAPAN TERIMA KASIH}

Penulis mengucapkan terima kasih kepada seluruh pihak yang membantu dalam pelaksanaan penelitian ini, terutama kepada PT. Geomosaic Indonesia yang telah memberikan dukungan berupa data zona nilai tanah baik data spasial maupun non spasial.

\section{DAFTAR PUSTAKA}

[1] "Letak Geografis - Solok Kota." https://solokkota.go.id/letakgeografis/ (accessed May 08, 2020).

[2] "BPS Kota Solok," 2018. https://solokkota.go.id/letak-geografis/.

[3] A. Sutawijaya, "Analisis Faktor-Faktor Yang Mempengaruhi Nila Tanah Sebagai Dasar Penilaian Nilai Jual Obyek Pajak (NJOP) PBB di Kota Semarang," J. Ekon. Pembang., vol. 9, no. 1, 2004.

[4] P. Kertopati, "Strategi Pemerintah DKI Jakarta dalam Rangka Optimalisasi Penerimaan Bea Perolehan Hak atas Tanah dan Bangunan (BPHTB).," Perbanas Rev., vol. 1 NOMOR 1, no. November, pp. 72-86, 2015, doi: 10.1016/j.bbr.2010.05.009.

[5] "Beranda|Direktorat Jenderal Pajak." https://www.pajak.go.id/. 